\title{
The Involvement of Budapest Residents with Visual Impairments in Leisure Sports: Barriers and Facilitators
}

Authors' contribution:

A) conception and design of the study

B) acquisition of data

C) analysis and interpretation of data

D) manuscript preparation

E) obtaining funding

\author{
Judit Gombás $^{1 \text { A-E }}$, Andrea Gál ${ }^{2}$ A-E , , \\ ${ }^{I}$ Eötvös Loránd University of Sciences, Hungary \\ ${ }^{2}$ University of Physical Education, Hungary
}

ABSTRACT

Since the political and economic changes that occurred in 1989-1990, Hungary has been in a state of transition from a socialist regime to a democratic culture. In an effort to comply with the rules of democracy, equal opportunities for people with disabilities are demanded on various platforms. However, inclusion in sports is still uncommon, and physical education (P.E.) teachers, trainers, sports scientists, etc. are not provided with in-depth education on adapted sports. The present study examines the involvement of Hungarian adults with VI (visual impairments) in leisure sports and investigates facilitators and barriers which members of the target group face. First, the educational opportunities (segregation or inclusion) provided for Hungarian children with VI are introduced. The historical and legislative backgrounds are presented in order to give a clear review of the social context. Findings of a survey on the activity levels of Hungarian adults with vision loss are introduced, which reflect the target group's willingness to get involved in leisure activities and also pinpoint factors which hinder their participation (e.g., professionals' unfamiliarity with the special needs of those with VI and adapted sports opportunities).

\section{KEYWORDS}

visual impairment, leisure, inclusion

\section{Introduction}

According to the findings of the Eurobarometer surveys from 2010 and 2014, the Hungarian population is among the physically least active nations in the EU. Data gathered in 2009 show that more than half $(53 \%)$ of the population has never been involved in any sports or athletic activity. Although the latest studies have detected positive tendencies - the number of those who have never been involved in any sport seems to have decreased to $44 \%$, and the percentage of individuals who are regularly involved in sports or athletic activities has increased to $15 \%$ from a very low $5 \%$ - involvement in leisure sports in Hungary is still far behind Scandinavian participation rates, where leisure sports are considered a national pastime. Research has also shown that the most underrepresented populations are women, elderly people, citizens with low socio-economic status, and individuals with disabilities (Dóczi et al., 2014; Gál, 2008). The present situation is even more worrying considering the increasing rates of obesity worldwide (Caballero, 2007) and all of the negative medical conditions which are directly linked to this trend. Some studies carried out during the last two decades have emphasized the fact that people with disabilities are significantly more likely to be obese 
than those without disabilities (Capella-McDonnall, 2007; Liou et al., 2005) due to their greater tendency to live sedentary lifestyles (Dolbow, \& Figoni, 2015).

It is undoubtedly true that more and more public attention is being paid to people with disabilities in Hungary. However, members of the target group often feel that social inclusion and accessibility are still concepts and theories instead of tangible practices. As a part of the comprehensive national sports strategy, it is important to investigate minority groups' involvement in leisure sports and games. This study introduces the social status of people with visual impairments (VI) in Hungary and takes a closer look at their involvement in leisure sports and activities. The research survey introduced in detail below sought answers for the following research questions:

1. To what extent are people with VI represented in leisure sports?

2. Is there a link between participation in adapted physical education and adult sports activity levels?

3. What is the target group's opinion on and personal experience with sporting habits and factors which promote or hinder their involvement in sports?

In order to provide an understanding of the "Hungarian case", the social and historical contexts are first introduced through a review of related literature. Whilst the literature on adapted sports is rich in the U.S. and Western Europe, few Hungarian studies investigate disabled and, more specifically, visually impaired individuals' leisure sports habits and opportunities. This is why the sports socialization of blind children and children with low vision and its institutional background can only be analyzed through resources written about school sports and physical education (P.E.). The dichotomy of segregation versus inclusion is examined via its pros and cons, as it is a key factor determining the social status of blind people and people with low vision. The profound analysis of the historical, educational, social, and scientific background is followed by a report on the findings of a survey conducted in the spring of 2012, and then plausible explanations of these findings are discussed.

\section{A brief history of the social status of people with disabilities and their sports activities in Hungary}

\section{The social status of people with disabilities}

Disabled persons have been ignored, often hidden, and even cursed throughout world history, including Hungarian history. The deep lack of knowledge about the very essence of disability and people's repugnance to those with special needs lessened only in the nineteenth century, when the contribution of progressive activists and the fight to change the inferior social status of the disabled started. However, society's attitudes and the treatment of people with disabilities have changed very slowly.

Although there have been some steps forward, the segregation of disabled persons was not regarded as discrimination for very long. Even in the second half of the twentieth century, it was considered a matter of fact in many countries. During this time, Hungary belonged to the Eastern Bloc and was a so-called "socialist country" until 1989. There is little statistical and research data available from this era concerning the social status of people with disabilities, since they were an almost invisible social minority with limited opportunities for social participation and integration (Komáromi, 2003). The stigmatization of people with disabilities and the generally accepted practice of segregation in education, employment, and sports resulted in a disadvantageous social status. After the political and economic system changed in 1989-1990, Hungary began to make efforts to meet the expectations of democracy, and a positive change occurred in the social status of people with disabilities. Their economic, political, legal, cultural, and social status has further improved since Hungary joined the EU in 2004. However, the heritage of the past can still be traced in the structure of the state and often in citizens' mentality as well.

In spite of the somewhat contradictory situation, the ratio of people who identify themselves as disabled has recently increased in Hungary. According to data gathered in the population census of 2011 by the Hungarian Central Statistical Office, disabled persons were $4.9 \%$ of the total population. A comparison of the respective numbers of the census of $1990(490,578)$ and those of $2011(577,006)$ shows a significant 
rise in the number of people with disabilities. The main reason for the outstanding increase is the fact that only $20 \%$ of respondents were asked about their health status, including disability, in 1990, while all participants were asked about this factor in 2011. A additional reason for the rise is supposedly that a higher number of respondents in 2011 had a clearer notion of their exact health status, which can be attributed to the fact that definitions of disability are becoming more and more precise (Tausz, \& Lakatos, 2004).

The data from 2011 show that physical impairment is the most common disability in Hungary (43.6\%), while people with VI are the second most numerous population with a disability (14.4\%).

\section{Sports for people with disabilities}

Disability sports were institutionalized in Hungary in 1929 when a sports club was founded for the physically disabled. For decades, this club had a good reputation in Europe because, in addition to rehabilitation, it also had physical training and sports competitions and adapted P.E. classes in its framework. Moreover, there were attempts to organize integrated events with both disabled athletes and those without disabilities. Unfortunately, after World War II, the new political regime put an end to this sports club. In the era of state socialism, when elite sports were a tool for achieving political goals, leisure sports, school sports, and disability sports were paid no attention by the government. Furthermore, as disabilities used to be considered deviations that did not fit the ruling ideology of the regime, disability sports also had to become invisible (Földesi et al., 2009). Nevertheless, sports for disabled athletes again gained support starting in the 1970s because sports policy regarded their participation in international competitions as important. In 1977, sports committees for the physically disabled, including people with hearing impairments and VI, were created by the highest sports authority and governed by the state. They focused on elite athletes, while ignoring leisure activities. The privileged role of elite sports over leisure sports was obvious, and disproportions between elite parasports and leisure sports for people with disabilities became even more conspicuous.

The change of the regime in 1989-1990 brought fundamental changes in disability sports, as disabled athletes became visible and gained growing public respect and increasing financial funds. In 1997, the Hungarian Paralympic Committee (HPC) was founded, and the rising democracy opened the way for other civic initiatives: non-governmental organizations started to promote active leisure and regular sports activity among people with disabilities.

Since Hungary joined the EU, disability sports have been given more attention in policy than ever before; legislative measures have been taken with the aim of promoting the participation of disabled people in sports.

Over the past two decades, four acts on sports have been ratified in Hungary (1996, 2000, 2004, and 2012). Act No LXIV of 1996 on Sports underlines the importance of supporting the participation of people with disabilities in sporting activities. The accessibility of sports facilities is first included in Act No CXLV of 2000 on Sports. However, it must be noted that the act refers exclusively to the necessity of access to the built environment and barrier-free communication; the accessibility of P.E. lessons or other training sessions is not mentioned. Act No I of 2004 on Sports details bureaucratic measures, such as the legal status and tasks of the HPC. A practical declaration of the act is that the needs of people with disabilities must be taken into consideration when inclusive sports events are arranged.

Although positive steps forward appear in these various acts, numerous key issues concerning sports and disability still lack the attention of policy makers. Most people with disabilities have little opportunity to become involved in leisure sports on a micro-level (e.g., training sessions). Full inclusion for all students is still expected at P.E. lessons and extracurricular school sports programs. In order to provide a high standard of inclusive educational activities as well as other sports services, future sports experts need specialized studies on sports and disability, and opportunities for lifelong learning need to be made available. It must be underlined that the concepts of adapted sports and adapted P.E. appear in none of these acts (Gombás, 2011), and unfamiliarity with the subject matter is characteristic not only in legislation, but also among 
sports professionals. A further gap in legislation related to the accessibility of sports and P.E. can be found in the binding act on public education (LXXIX/1993). According to $\$ 69$, the director of a school has the right to exempt students from studying talent-based subjects (in the Hungarian context of education, arts, music, and P.E. are called talent-based subjects) if the student's ability or other conditions explain the exemption. The act contains no guidelines concerning inclusion, and the concept of adapted sports does not appear here, either.

\section{The education of students with VI}

As with children without disabilities, educational opportunities are crucial in the sports socialization process of children with VI. Therefore, this article will briefly introduce schooling options for students with VI.

The specialized education of blind children in Hungary dates back to 1825, when the first institute for blind people was opened in Budapest; it was one of the first institutions with similar aims in Europe. The teaching of blind children in special schools at that time cannot be regarded as segregation in today's meaning of the term, but rather as a progressive step. Blind children and children with VI were educated together over long decades; they were not educated separately until a century later. During these decades, the fields of education broadened, and music and sports, among other subjects, were introduced.

In the mid-twentieth century, Hungary was not involved in the sharpening professional debates which began in some western countries about the proper relationship between special education and general education. During this period, the existing system of state socialism in Hungary neglected disability-related issues in general and favored segregation in education. Some experts believed that students with disabilities developed better among their peers with similar disabilities in an environment that was adapted to their special needs. According to these experts, it was a further advantage that the groups from which children with disabilities were excluded became more homogenous; in other words, they believed that the exclusion of children with special needs was beneficial for children without disabilities (Somorjai in Bánfalvi, 2008). Consequently, the country had separate school systems for mainstream children and children with special needs.

This structure of education did not change until the period following the political system change in 1989-1990. As a result of the Act of 1993 on Public Education (LXXIX), various disabilities were categorized, and the term "disability" had to be used rather than "special needs". The 1993 Act on Public Education was the first ever legislative tool in Hungary to declare that children with disabilities have the right to study in inclusive settings.

Since that time, the amount of research on integrated versus segregated education has multiplied. Petö and Szabó (2003) claim that segregated education leads to social isolation, hinders personal development, and decreases the social acceptance of individuals who are different for any reason. Among the negative effects of segregated education, Bánfalvi (2008) notes that while segregated education has always been financed by the state and has provided children with specialized education, it may, de facto, imply lifelong social segregation, as children without disabilities do not learn to accept differences between the disabled and the non-disabled during the process of socialization. Kálmán and Könczei (2002) highlight the idea that participation in segregated education may lead to poor social skills, which form a strong disadvantage in the labor market. They also point out that employees with special needs are often treated with prejudice by employers. It is therefore undoubtedly true that segregation has negative and tangible lifelong effects.

In the 1990s, an increasing number of families had to find an inclusive institution for their children. The Act on Public Education brought new, positive perspectives to the lives of families. Segregated education meant that many families had no other choice but to send their children with VI to distant boarding schools. It was a traumatic experience for the whole family (Haugann, 1991) and separation from the family was an additional handicap for those living anyway with fewer opportunities (Réthy, 2002). While the act was meant to allow these children to attend local schools, the appropriate scenarios for education (accessible school buildings, accessible materials, individualized teaching methods, adapted teaching equipment, etc.) 
were all missing, bringing about challenges for educators. The fact that teachers were not prepared to include students with VI in mainstream lessons demanded the creation of a specialized service. "Itinerant teacher services", arranged within the framework of special primary schools, were founded in the 1990s. Teachers working at mainstream institutions at that time, and unfortunately in current times as well, were not prepared during their college or university studies to educate students with disabilities.

As inclusion in education means that all students are provided equal access to every subject, P.E. must not be an exception (Kälbli et al., 2015). Several studies underline the fact that the target group's equal participation in P.E. lessons has not been achieved. In a study conducted among 20 blind people living in Budapest who are members of a sports club and are regularly involved in sports, respondents asserted the opinion that studying in mainstream settings is a barrier to engaging in leisure sports (Osváth, \& Ramocsa, 2006). The statement above is acceptable if we consider the fact that P.E. teachers often insist on the exemption of students with VI from taking part in P.E. lessons with peers who do not have VI, as these teachers do not have specialized education on adapted sports and the necessary requirements for successfully adapting the subject. Since the exact number of students who are involved in inclusive lessons is not known and is continuously changing, the proportion of those exempted from P.E. is also unknown. Further empirical studies (Somorjai, 2008; Perlusz, 2008) highlight the fact that although exemption in mainstream schools is not an overused tool, P.E. is one of the most problematic fields of education, as it requires a large number of adaptations, and therefore an exemption from participating in these lessons is most often decided upon. In many cases, students are not fully excluded from the sports activity, and participation in regular swimming or curative P.E. lessons is recommended. Less lucky students, especially those who are totally blind, completely stay away from sports, and this distance from sports in childhood results in adult passivity (Osváth, \& Ramocsa, 2006). A survey conducted amongst 582 university students of P.E. by Osváth et al. (2007) on their knowledge of sports for individuals with VI proves that, although the future sports experts have a positive attitude towards blind people and their sports participation, these students' poor familiarity with disability and the lack of disability-related courses during their college and university education prevents them from becoming involved in disability sports. The researchers emphatically assert that students should not be allowed to graduate without specific knowledge on sports activity and disability.

Currently, there are three segregated residential schools for students with VI in the country, and the number of segregated students decreases every year. Inclusion in education is a new phenomenon in the Hungarian schooling system.

\section{Methods}

A research survey was carried out in order to gain an understanding of the leisure patterns of Hungarians with VI, with a focus on the frequency of involvement in leisure sports (walking included). The present study introduces the results related to residents of Budapest with VI aged 18-65 years old $(\mathrm{N}=140)$.

VI is a term which refers to a very heterogeneous population. This is why the definitions applied in different countries and often by different sciences vary. When speaking about blindness, most people believe that blind individuals cannot see anything at all (Csákvári, 2009). The World Health Organization (WHO), in accordance with the International Classification of Diseases, differentiates four levels of visual function: normal vision, moderate VI, severe VI, and blindness. The term "low vision" comprises severe and moderate VI, while low vision and blindness together represent all VI (WHO, 2014). The three degrees of VI determined by the International Federation for the Blind (IBSA) and applied worldwide are named class B1 (blind), B2 (severe VI), and B3 (moderate VI), depending on the individual's visual acuity. In Hungary, the three classes of VI are blindness, low vision, and partial sight. Though the term "partially sighted" is outdated in the United States (Lieberman et al., 2013), the research was based on Hungarian standards and therefore applies Hungarian classification. Any research related to VI must clearly describe the ophthalmologic status of the individuals studied, since a blind person faces completely different difficulties than those of a person with low vision. Similarly, discrepancies must be investigated among those with 
congenital blindness and those with acquired VI, since people who are born with a visual deficit and those who live a certain part of their lives as sighted people face different challenges and barriers. It was therefore important to know the proportion of those born with congenital eye diseases (69.3\%). Less than a third of the respondents indicated that a partial or complete loss of their eyesight occurred after birth. Almost half of the sample (49.3\%) was blind, a third (30.0\%) had low vision, and $20.7 \%$ were partially sighted.

The proportion of genders was balanced in the sample: $47.9 \%$ were male, and $52.1 \%$ were female. Concerning their age, $67.9 \%$ (95 people) were aged 19-35 years old. A total of 17.1\% were aged 36-50 years old, and 13.6\% were aged 51-65 years old. Less than 10\% (13 respondents) reported that they had completed some or all of the eight classes of primary school, without further education. A total of $88.5 \%$ completed secondary education and the leaving exam, and many of them continued their studies and received a degree in an institute of higher education (44.2\%). A sizeable proportion of respondents $(59.3 \%)$ confirmed that they were engaged in paid employment, and $9.3 \%$ were unemployed. The "other" category comprised, for instance, mothers on childcare leave. In relation to their employment status, we investigated the respondents' subjective financial status. A surprisingly high percentage (68.6\%) claimed that their monthly income was satisfactory and indicated that they also had savings. Less than $10 \%$ said they were unable to make a living.

In order to find out whether inclusive or segregated school settings have a favorable effect on the future leisure sports activity levels of children with VI, it was essential to know what type of institution the respondents were educated in. Some of them (20.0\%, or 28 individuals) attended a kindergarten for children with VI, while $60.0 \%$ (84 respondents) studied in a segregated primary school for either blind or partially sighted children. Finally, $4.3 \%$ (6 persons) reported to have studied or were currently studying at a special secondary school.

The data was collected by a 43-item questionnaire completed on a voluntary basis by the respondents. The research was based on key issues, the combination of which (accessibility + regular involvement + opportunities for inclusion) determines the target group's access to recreational sports activities. Since contacting the target group was most efficient via electronic tools, the research was completed via electronic snowball sampling. This is a non-probability sampling technique often used when access to members of the studied population is poor. Additional respondents were contacted via several different lists consisting of blind and partially sighted individuals and run by vision-impairment-related organizations. Information about the study was also spread on Facebook. Respondents either filled in the online form in Google Docs or sent the completed document to a pre-defined e-mail address. The questionnaire contained open, multiple-choice, and closed questions.

The results were analyzed with simple statistical methods and chi-squared tests. Data analysis was followed by the interpretation of data, in line with the research questions. As the first author of this article is herself visually impaired and was for many years the president of a non-governmental organization offering accessible leisure opportunities for the visually impaired community, data collection and empirical research were completed using her professional and personal experience.

\section{Findings}

The results are presented in three sections. First, the leisure habits of people with VI are explored, with particular attention given to their participation in sports and games. Second, the relationship between participation in adapted P.E. and the sports activity level of adults is analyzed. Third, barriers to and facilitators of the involvement of individuals with VI in leisure sports are explored.

\section{Sports and leisure habits of adults with VI}

When investigating a certain target group's sporting habits, it is important to know to what extent leisure sports activities are a part of their life and what other interests they spend their free time on. This is why we investigated how frequently (every day, every week, every month, a couple of times a year, hardly 
ever, never) respondents engaged in other activities: watching television, going to the cinema, recreational shopping, reading books or listening to audiobooks, going to cultural events (theatre productions, museums, concerts, etc.), meeting relatives, meeting friends, playing cards or boardgames, listening to music, doing other types of physical activity, cheering at sports events, making handcrafts, and surfing the Internet. According to the findings, $52.9 \%$ of the research population claimed to participate in sports or walk on a weekly basis. The most popular sports among the respondents included walking, running/ jogging, and swimming. An equal number $(\mathrm{N}=20)$ preferred biking or tandem biking and/ or hiking. It must be noted that there is no research data on the frequency of involvement in the named activities.

Among daily activities, however, those of a less active nature appear: watching television $(49.3 \%)$ and listening to music (more than $80.0 \%$ ) were very popular free time activities among the respondents. The respondents' frequency of Internet use (90\% on a daily basis) might be shocking, as it is clearly a sedentary activity. However, as these people have VI, it must be taken into account that access to news and information is most easily available to them online. The spread of information about sporting opportunities could therefore be easily achieved via electronic channels.

\section{Childhood involvement and adult participation}

The study found a relationship between involvement rates in sports and the frequency of exemption in primary and secondary school. The survey aimed to measure the proportion of those who participated in P.E. and those who were exempted. The results show that only $8.6 \%$ of students were exempted from participating in regular P.E. lessons during primary school, $82.9 \%$ took part in the lessons, and $8.6 \%$ were sent to curative P.E. lessons. The proportions are much less satisfactory in the case of secondary schools: 44.3\% were exempted, $47.1 \%$ participated in general P.E. lessons, and 8.6\% participated in special P.E.

According to the results, regular participation in any sports activity (P.E. lessons or extracurricular sports) during the school years directly results in involvement in leisure sports activities in adulthood. Only $38.1 \%$ of the population failed to become involved in any sports or athletic activities; the rest attended curative P.E. or other afternoon sports activities. While $58.1 \%$ of those who took part in such activities during their school years claimed to participate in sports on a daily/ weekly basis in their adulthood, a lower proportion of those who were not involved in sports in their childhood are active adults $(40.8 \%)$. The chisquared distribution also verified the discrepancy between the two groups $(\chi 2=28.453, \mathrm{df}=10 ; \mathrm{p}<0.05)$.

The research provided information on the frequency of participation in sports by comparing student participation rates and adult involvement. Of those who participate in sports once or twice per week on average as adults, $62.8 \%$ took part in extracurricular sports activities in their youth. The chi-squared distribution also verified the discrepancy between the two groups $(\chi 2=33.71, \mathrm{df}=10 ; \mathrm{p}<0.05)$.

\section{Barriers to sports participation encountered by individuals with VI}

Success or failure experienced during childhood sports socialization determines adult involvement in sports. Furthermore, in the case of people with disabilities, the accessibility of leisure sports activities is a highly influential issue to tackle. Hungary was the first EU member state to ratify the UN Convention on the Rights of Persons with Disabilities and its Facultative Protocol. In accordance with the convention, accessibility for people with disabilities is demanded by legislative regulations. The Facultative Protocol demands the identification and elimination of barriers and obstacles both of the built environment (buildings, transportation, etc.) and information, communication, and other services (article 9). The binding act on sports defines what the accessibility of sports scenarios means and underlines the necessity for urgent action; however, it does not mention the need for accessible sports services. Our results highlight how the lack of accessible design is a factor that significantly determines disabled individuals' willingness to get involved in sports activities. The research attempted to detect barriers that appear on a micro-level. One of these, closely linked to accessibility, is the lack of adapted sports tools. According to the findings, less than $20.0 \%$ of the 
research population is in possession of a tandem bike. The number of bell ball owners is even lower, at 17 out of the total sample of 140 .

We also attempted to acquire information on the research population's knowledge about accessible sports services, i.e., associations and foundations which promote visually impaired individuals' participation in leisure sports. The following two types of organizations were named:

1. Segregated associations, founded with the aim of providing sports exclusively for the visually impaired community (e.g., the Sport Association for Blind Students or the Sport Association for Partially Sighted Students);

2. Explicitly inclusive organizations, founded with the goal of bridging social gaps among sighted and non-sighted, or more generally, disabled and non-disabled, people via sports (e.g., the Sports and Leisure Association for the Visually Impaired or the Suhanj! Foundation).

About $75.0 \%$ of the population $(\mathrm{N}=104)$ named at least one organization from either of the two types listed above.

By analyzing the research population's first hand experiences, opinions, and impressions related to leisure sports and disability, the researchers explored factors that promote their sports participation and others that stop them from getting involved in physical activity. Data analysis showed that engaging in sports with their peers is one of the most inspiring factors for most respondents. The majority of them said that being active alone is much harder, while a group of visually impaired peers, or simply a kind, sighted guide makes the effort to start much easier. In many cases, the low cost of a given sports activity appears to be a motivating factor, which may indicate that the target group is far from being well-off or shows a low willingness to spend money on sports.

The list of discouraging factors contains both human and materialistic elements. Several respondents expressed their fear of encountering coaches who have no knowledge about working with individuals with VI. Difficulties of orientation inside the sports scenario and the individual's subjective opinion of his or her own poor mobility skills also keep visually impaired people away from sports. A low number of respondents mentioned that they find it hard to find sighted guides. Research data, however, show that sighted people who are frequently involved in sports in their everyday lives volunteer for this role with great enthusiasm, and their most important motivation is to share the joy of sports with their non-sighted peers; significantly, pity is almost totally missing from their motivating factors (Gombás, 2013).

\section{Discussion and Conclusions}

This study aims to present the leisure patterns of the visually impaired residents of Budapest, focusing on the motivating and discouraging factors that are influential in their involvement in leisure sports. Despite the fact that the data collected via the research survey fail to represent the whole community with VI living in Budapest, it has undoubtedly achieved its goal of mapping at least some of the fundamental difficulties and barriers that the target group experiences and reflects some tendencies in their attitudes towards leisure sports activity.

Our results indicate that a high number of mainstream institutions are not prepared for involving students with VI in P.E. lessons; this problem is seemingly solved by exempting the students from lessons. This assumption is partly confirmed by our findings: participation rates during primary school years are surprisingly high. It is, however, important to remember that more than $60 \%$ of the sample attended a segregated primary school. The results of secondary school P.E. are much less satisfactory; although schools are required to provide equal opportunities for students with special needs, and therefore they are being included more and more often, P.E. teachers fail to receive specialized education and have no teacher support services they can turn to for information on how to adapt their teaching methods and the environment to fulfill the requirements of accessibility and inclusion. The uncertainties of sports practitioners are clearly felt by visually impaired individuals, who are highly likely to avoid participating in 
sports due to their fear of not being included in a sporting group by a coach or P.E. teacher who is unfamiliar with their special needs. Adult participation rates are fortunately higher than expected. It must be underlined that, as data on education, finances, and employment show, the sample represents a segment of the group of people with VI who have a relatively good socioeconomic status.

A milestone in promoting the lifelong sports participation of both visually impaired children and adults is accessible design, including the built environment and adapted equipment. In Hungary, sports facilities are poorly accessible, and facilities that theoretically meet the needs of all users with disabilities often prove to be accessible only for wheelchair users, not for people with VI. The lack of accessibility is a barrier not only for those involved, but also for sports experts. P.E. teachers can offer blind students a much wider range of activities if bell balls or guiding wires are at their disposal. Simple adapted tools, such as bell balls, should be part of each blind person's household, just as sighted families have at least one ball.

As the research population's levels of sports activity show, those living in Budapest are provided with at least some sporting opportunities by specialized NGOs. Following the guidelines of social inclusion, these opportunities should be available countrywide in heterogeneous communities of athletic people. Services provided by local sports clubs need to be adapted to include special-needs consumers in their daily activities. They may become truly inclusive if they make tandem bikes or hand bikes available for rent. The possession and efficient use of adapted equipment is an essential tool for including non-sighted individuals in a sighted group, independent of the age of the visually impaired individuals.

In investigating opportunities for promoting sports activities among people with vision loss, the present study shows that a deficit of information is a key factor that keeps all parties from becoming involved in inclusive leisure sports activities either as service providers (coaches, P.E. teachers, etc.) or visually impaired consumers. As the numbers show, the target group is only partially informed about adapted opportunities, organizations, and equipment. Their involvement may, however, be multiplied if all areas of sports become more open to individuals with disabilities in their daily functioning.

It is essential to take urgent measures to incorporate disability-specific knowledge into the education of teachers, coaches, and other staff of sports-related activities. The participation of volunteers is a great asset for disability sports. Volunteers' enthusiasm and effort is a building block that experts can implement with great success in working with visually impaired individuals. However, proper information on assistive strategies must be shared with volunteers beforehand in order to provide smooth cooperation and the personal safety of both visually impaired participants and sighted guides during the activity. Information provided by the person who needs assistance is invaluable. However, expert knowledge is inevitable in cases where the visually impaired person is unfamiliar with possible adaptive techniques. As many sports are inaccessible for people with low vision, volunteers play a crucial role in increasing their participation rates in leisure sports activities. Thus, experts must have a clear understanding of the role of volunteers; they must also understand that quality sports services are built on well-informed sports experts' specialized knowledge on disability-related issues.

Sports have a high potential for reducing stereotypes linked to disability because they "can transform attitudes about persons with disabilities by highlighting their skills and reducing the tendency to see the disability instead of the person" (SCRPD 2012).

Sports are a positive context in which disabled and non-disabled people can meet; they act as a platform that empowers people with disabilities to demonstrate their skills and abilities and advocate for themselves. In Hungary, policy needs to be more focused on this issue in order to strengthen the positive tendencies that have already appeared in society and further encourage people with VI to get involved in leisure sports on a regular basis.

\section{Acknowledgements}

We would like to express our gratitude to our colleague and friend, Attila Velenczei $(\dagger)$, for devoting his time and knowledge to the present project and providing us all of the technical support we needed. 


\section{REFERENCES}

Abraham Bánfalvi, Cs. (2008). Az integrációs cunami /The integrating tsunamil. Budapest: ELTE Eötvös Kiadó Kft. Caballero, B. (2007). The global epidemic of obesity: An overview. Retrieved August 15, 2015, from http://epirev.oxfordjournals.org/content/29/1/1.full

Capella-McDonnall, M. (2007). The need for health promotion for adults who are visually impaired. Journal of Visual Impairment and Blindness, 101, 133-145.

Csákvári, J. (2009). A közös figyelmi helyzet jelenségének különbözzö megközelitései, jellegzetességei látássérülés és autizmus spektrum zavar esetén /Different aspects and specific features of joint attention deficit in children with visual impairments and autism spectrum disorder/. Retrieved April 10, 2015, from http://www.prae.hu/prae/gyosze.php?menu_id=102\&jid=23\&jaid=205

Dóczi, T., Gál, A., \& Sáringerné, Sz.Zs. (2014). Társadalmi befogadás a sportban és a sport által /Social inclusion in sport and through sport/. In J. Farkas (Ed.), A fizikai aktivitás és a sport magyarországi dimenzióinak feltárása /Exposition of dimensions of physical activity and sport in Hungary/, (pp. 74-141). Budapest: MST-MSTT.

Dolbow, D.R., \& Figoni, S.F. (2015). Accommodation of wheelchair-reliant individuals by community fitness facilities. Spinal cord. Retrieved August 20, 2015, from http://www.ncbi.nlm.nih.gov/pubmed/25777328

Földesiné, Sz.Gy. (1997). Proklamáció a fogyatékosok sportjáért /Proclamation for disability sports/. Testnevelés és sporttudomány/Physical education and sports sciencel, 2, 9-16.

Földesiné, Sz.Gy., Gál, A., \& Dóczi, T. (2009). Sportszociológia /Sociology of sport/. Budapest: TF-MSTT.

Gál, A. (2008). A magyar lakosság egészségtudatossága és szabadidő-sportolási szokásai /Health status and sporting habits of Hungarian population/. In Sz.Gy. Földesiné, A. Gál, \& T. Dóczi (Eds.), Társadalmi riport a sportról /Social report on sport/, (pp. 9-39). Budapest: ÖM Sport Szakállamtitkárság, MSTT.

Gombás, J. (2011). Fogyatékosok sportja helyett adaptált sport - avagy a szemléletváltás jótékony hatása /Disability sports or adapted sports: The beneficial effect of new approaches/. Magyar Sporttudományi Szemle /Hungarian Sport Science Review/, 4, 27-31.

Gombás, J. (2013). Sighted volunteers' motivations to assist people with visual impairments in free time sport activities. Journal of Human Sport and Exercise, 8(2), 220-227.

Haugann, E.M. (1991). Strengths and weaknesses of integrated education and special schools for the blind: An international perspective. Retrieved August 15, 2015, from https://nfb.org/images/nfb/publications/fr/fr10/issue1/f1001tc.html

Hungarian Central Statistical Office (2012). Population census 2011. Retrieved June 10, 2012, from http://www.nepszamlalas2001.hu/eng/volumes/12/tables/load1_1_1_2.html

Kálmán, Zs., \& Könczei, Gy. (2002). A Tajgetosztól az esélyegyenlöségig /From Taygetos to equal rights/. Budapest: OSIRIS.

Keszi, R., Pál, J., \& Papp, G. (2014). Fogyatékosügyi szervezetek együttmüködési kapcsolatai Magyarországon Pillanatfelvétel a nonprofit szektor egyik speciális szegmensének hálózatszervezödési karakterisztikájáról /Cooperative relations of disability organizations in Hungary: Snapshot about the characteristics of network organization related to a special segment of the non-profit sectorl. Retrieved August 19, 2015, from http://www.prae.hu/prae/gyosze.php?menu_id=102\&jid=48\&jaid=674

Komáromi, R. (2003). A megváltozott munkaképességü és fogyatékos munkavállalók munkaerő-piaci integrációjáról /Integration of people with disabilities to the labor market/. Esély, 5, 27-59.

Lieberman, L.J., Ponchillia, P., \& Ponchillia, S. (2013). Physical education and sport for individuals who are visually impaired or deafblind: Foundations of instruction. New York, NY: American Federation of the Blind Press.

Liou, T-H., Pi-Sunyer, F.X., \& Laferrere, B. (2005). Physical disability and obesity. Nutrition Reviews, 63, 321-331.

Osváth, P., \& Ramocsa, G. (2006). A sport hatása a vakok életminőségére Magyarországon /The effect of sport on blind people's quality of life in Hungary/. Kalokagathia, 1-2, 170-175.

Osváth, P., Kälbli, K., \& Ramocsa, G. (2007). Attitudes of students in sport education to the sport activity of blind people in Hungary and possible reasons for them. Retrieved October 6, 2012, from http://gymnica.upol.cz/index.php/gymnica/article/view/36/33 
Perlusz, A. (2008). Látássérültek iskoláztatása és társadalmi integrációja /Schooling and social integration of the visually impaired/. In Cs. Bánfalvi (Ed.), Az integrációs cunami /The integrating tsunami/, (pp. 113-129). Budapest: Eötvös Kiadó.

Pető, I., \& Szabó, É. (2003). Gondolatok a sérült gyermekek inklúziójáról /Thoughts on the inclusion of children with disabilities/. Retrieved February 19, 2012, from http://www.ofi.hu/tudastar/gondolatok-serult

Réthy, E. (2002). A speciális szükségletü gyermekek nevelése, oktatása Európában; Az integráció és inklúzió elméleti és gyakorlati kérdései /The education of children with special needs in Europe: Practical issues of integration and inclusion/. Magyar Pedagógia /Hungarian Education/, 102(3), 281-300.

Secretariat for the Convention on the Rights of People with Disabilities (SCRPD) (2015). Un Enable - Disability and sports. Retrieved February 14, 2016, from http://www.un.org/disabilities/default.asp?id=1563

Somorjai, Á. (2008). Integráltan és szeparáltan tanuló vak fiatalok /Blind students learning in integration and segregation/. In Cs. Bánfalvi (Ed.), Az integrációs cunami /The integrating tsunamil, (pp. 77-112). Budapest: Eötvös Kiadó.

Special Eurobarometer 213 (2004). The citizens of the European Union and sport. Retrieved June 22, 2010, from ec.europa.eu/COMMFrontOffice/.../index.cfm/.../54300

Special Eurobarometer 334 (2010). Sport and physical activity. Retrieved October 18, 2014, from europa.eu/rapid/press-release_MEMO-14-207_en.htm

Tausz, K., \& Lakatos, M. (2004). A fogyatékos emberek helyzete /Social status of people with disabilities/. Retrieved June 10, 2012, from http://www.ksh.hu/statszemle_archive/2004/2004_04/2004_04_370.pdf

Tóthné Kälbli, K., Fótiné Hoffmann, É., \& Lénárt, Z. (2015). Az adaptált fizikai aktivitás és az adaptált testnevelés fejlődése és jelentéstartalmának sokszínüsége a nemzetközi és hazai színtéren /Development and multiaspect natures of adapted sport and adapted physical education/. In L. Révész, \& T. Csányi (Eds.), Tudományos alapok a testnevelés tanításához. II. kötet. A testnevelés és az iskolai sport neveléstudományi, pszichológiai és kommunikációs szempontú megközelítései /Scientific fundaments of physical education. Volume 2. Didactic, psychological and communicational aspects/, (pp. 198-224). Budapest: Magyar Diáksport Szövetség.

World Health Organization (2014). Visual impairment and blindness. Retrieved August 18, 2015, from http://www.who.int/mediacentre/factsheets/fs282/en/

\section{AUTHOR'S ADDRESS: $\quad$ Andrea Gál}

University of Physical Education

22 Alkotás Street

P.O. Box: 69

Budapest 1525, Hungary

E-mail: gala@tf.hu

Received: 20 January 2016; Accepted: 9 March 2016 